\title{
Detecting spatiotemporal variability in the physicochemical properties of water in the Lower Mearim using remote sensing data
}

\author{
George Colares Silva Filho '; Diego Rosa dos Santos "; Isael Coelho Correia III; \\ Ingrid Santos Gonçalves Iv; Juliana Karolliny da Silva Ferreira v; \\ Paulo Cesar Mendes Villis VI; Fabrício Brito Silva VII
}

\begin{abstract}
Natural or anthropogenic chemical compounds of different origins often accumulate in estuarine regions. These compounds may alter the water quality. Therefore, It is important to constantly monitor the quality of estuarine regions. A combination of remote sensing and traditional sampling can lead to a better monitoring program for water quality parameters. The objective of this work is to assess the spatiotemporal variability of the physicochemical properties of water in the lower region of the Mearim River and estimate water quality parameters via remote sensing. Samples were collected at 16 points, from Baixo Arari to the mouth of the watershed, using a multiparameter meter and Landsat 8 satellite images. The physicochemical parameters of the water had high salinity levels, between 2.30 and 20.10 parts per trillion; a high total dissolved solids content, between 2.77 and $19.70 \mathrm{~g} / \mathrm{L}$; and minimum dissolved oxygen values. Estimating the physicochemical properties of the water via remote sensing proved feasible, particularly in the dry season when there is less cloud cover.
\end{abstract}

Keywords: Physicochemical properties; Remote sensing; Water quality

\footnotetext{
' University of CEUMA, São Luís, Brazil.: georgecolares@yahoo.com.br

"University of CEUMA, São Luís, Brazil. profdiegorosa@gmail.com

III University of CEUMA, São Luís, Brazil. isaelcorreia@outlook.com.br

Iv University of CEUMA, São Luís, Brazil. ingrids_goncalves@hotmail.com

v University of CEUMA, São Luís, Brazil. julianakarollinytrab@gmail.com

vi University of CEUMA, São Luís, Brazil. paulo.villis@ceuma.br

VII University of CEUMA, São Luís, Brazil. fabricio.brito@ceuma.br
} 


\section{INTRODUCTION}

Variations in water salinity are a key part of biochemical processes in estuary regions (LI et al., 2018; BERNHARD et al., 2005). The spatiotemporal variations in and magnitude of the physicochemical properties of water influence the socioeconomic conditions of populations living around estuarine regions (BASU AND ROY, 2018).

In addition to salinity, water properties including temperature, dissolved oxygen, and turbidity are known to affect aquatic life (DANESHVAR et al., 2007).

Estuaries are complex and dynamic environments that receive a large amount of human waste from urban and industrial areas (LIU et al., 2003; REESE et al., 2019)

Many methods have been used to study the effects of human activities on aquatic environments. They include the use of chemical and physical parameters, as well as biological measurements of bacteria, fish, and other aquatic organisms (RESH AND UNZICKER, 1975; HERNÁNDEZ, 2019).

The conventional techniques for water assessment are generally expensive (particularly in developing countries), slow, and unable to provide large study area and continuous analysis for water bodies with few sample points (KHATTAB AND MERKEL, 2014).

Monitoring stations placed in waters could provide these data, although they involve high operating costs such as equipment purchase, installation, field assistant salary, maintenance, and field trips (PACA et al., 2011).

Local investigations conducted only at the point scale are unable to evaluate the spatial distribution of salinity in all estuarine surfaces. Satellite images, however, cover regular intervals and provide data on solar radiation reflected by superficial waters that could be correlated with water quality properties (WANG AND XU, 2008).

Samples using remote sensing have some advantages such as the large spatial coverage of satellite images, ability to estimate water quality in remote and inaccessible areas, and a long record of archived images that allows the estimation of historical water quality (HELLWEGER et al., 2004; BAIQIAN et al., 2019). 
A combination of remote sensing, GIS, and traditional in situ sampling could lead to a better assessment of water quality parameters in several water systems (GHOLIZADEH AND MELESSE, 2017).

The goals of this study were to evaluate the spatiotemporal variability of the physicochemical properties of water in the lower course of the Mearim River and to estimate water quality parameters via remote sensing.

\section{MATERIALS AND METHODS}

\subsection{Study area}

The watershed of the Mearim River, located in the state of Maranhão (MA), northeastern Brazil, is a sub-watershed in the 12 watersheds of the hydrographic region of the Northeast Atlantic. It is pread over an area of $99.058 .68 \mathrm{Km}^{2}$ and corresponds to $29.84 \%$ of the area of MA; thus, it is the largest watershed in the state (Maranhão, 2011).

Another characteristic of this estuarine region is that geomorphologically, according to the classification developed by Pritchard (1952), it is a coastal plain characterized by shallow regions up to 30 meters deep. Sedimentation is a recent process here because the river bottom is muddy and the superficial part contains fine sediments.

As the study area is an estuarine region, tidal variation directly influences its water properties (MIRANDA et al, 2002). Another factor that must be considered is seasonality. The flow of the Mearim River increases during rainy season while the volume of water drained by the watershed decreases during the dry period.

The mainstream of the Mearim River has its headspring in the Serra da Menina, between Formosa da Serra Negra, Fortaleza dos Nogueiras, and São Pedro dos Belentes. Its mouth is between São Luís and Alcântara (Figure 1) in the bay of São Marcos. The maximum altitude of the watershed is approximately $650 \mathrm{~m}$. The main tributaries of the Mearim River are Pindaré and Grajaú rivers. 
This water complex reaches 83 cities and a total population of more than 1.600.000 people, corresponding to approximately one-quarter of the population in MA.

Figure 1 - Watershed of the Mearim River in Maranhão state, (b) low course of Mearim River and (c) digital elevation of study area in Mearim mouth

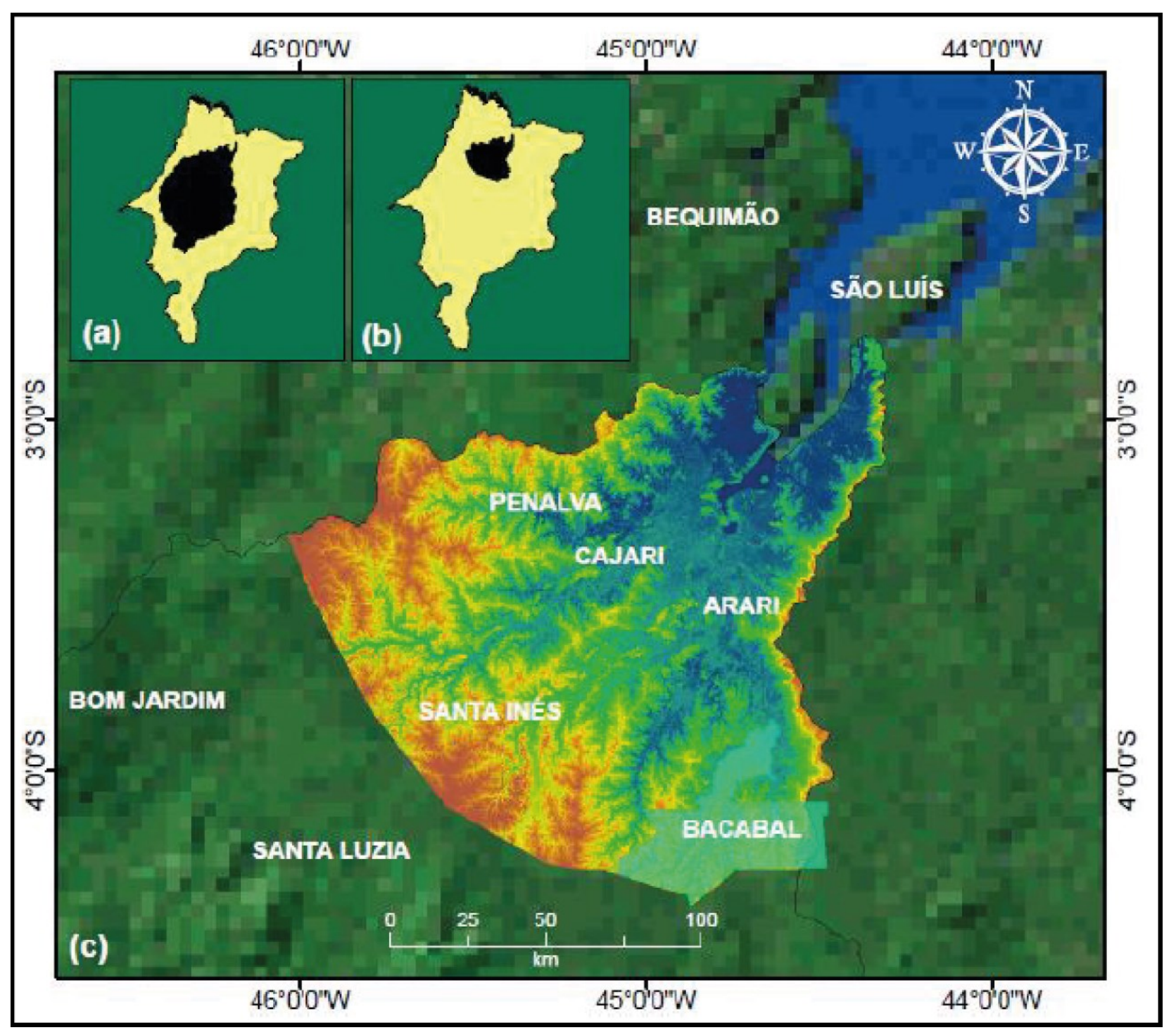

\subsection{Sample points}

Samples were collected from the river at 16 points (Figure 2), starting from the city of Arari, MA, and concluding near the mouth of the watershed. 
Figure 2 - Sampling sites (image from Google Earth, 2018)

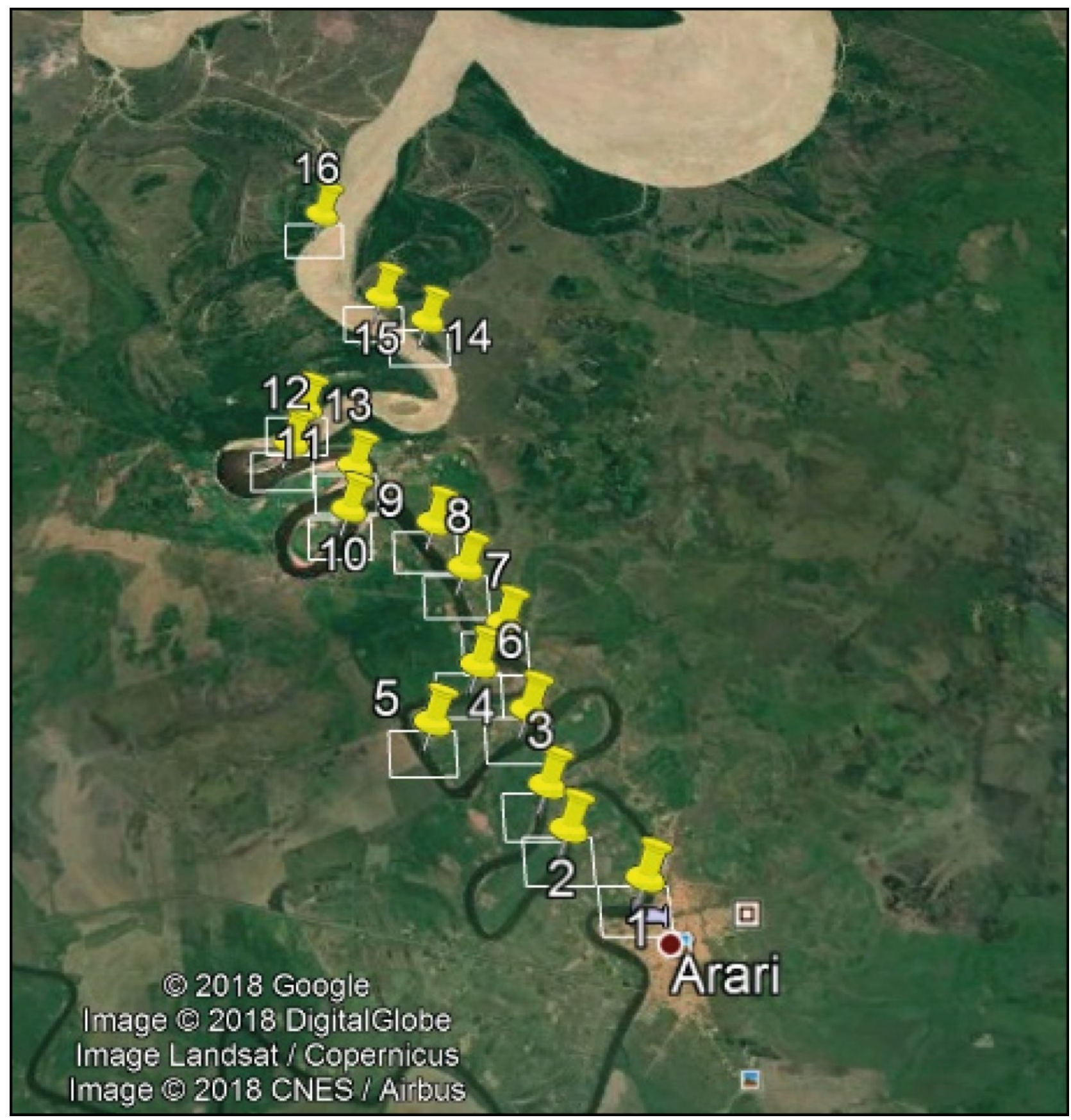

The samples also accounted for the rainy, intermediate, and dry seasons. Precipitation data for the climatological normal periods in 2016 and 2017, obtained from a meteorological station at Bacabal, showed that the months of high rainfall start from January to May, June is an intermediate month, and the dry season occurs from July to October (Figure 3). 
Figure 3 - Precipitation data for the period studied and the climatological normal as obtained from the Bacabal climatic station

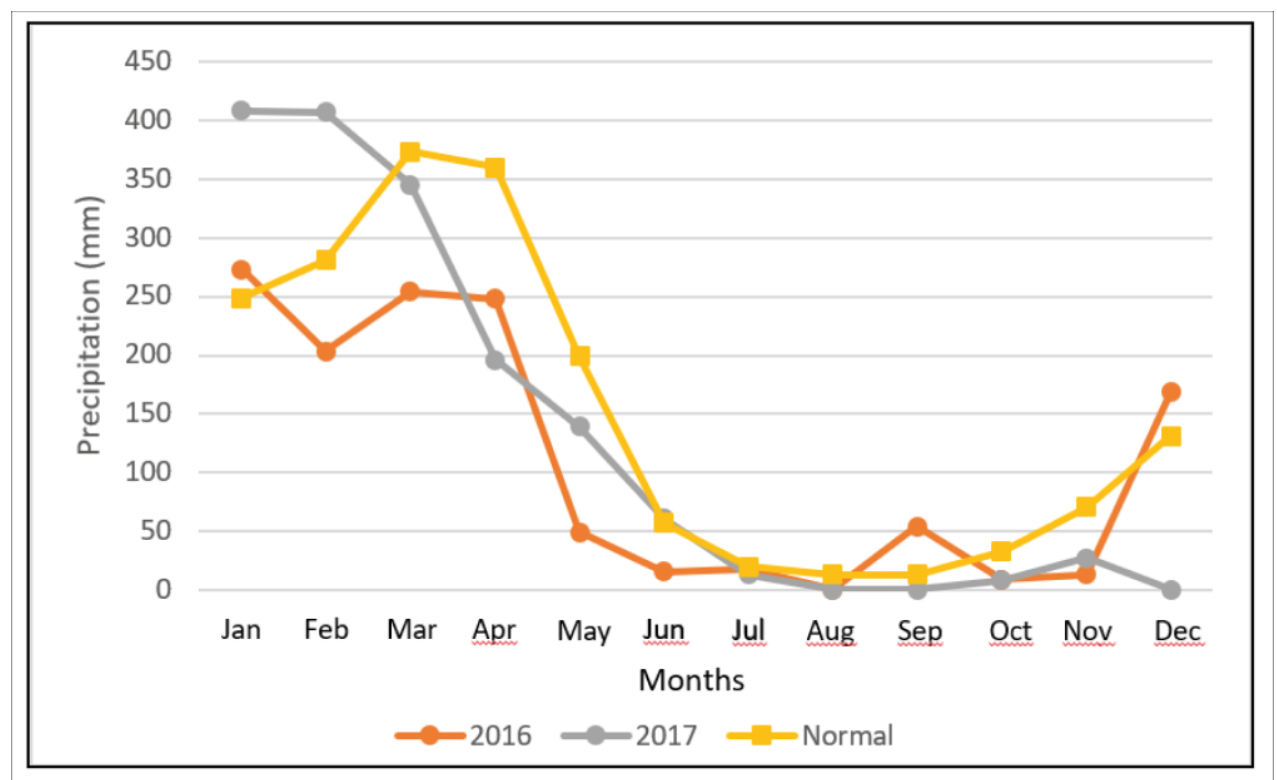

\subsection{Field samples of river water}

Water samples from the Mearim watershed were taken at sites along a course including Arari, Porto de Santana, Bonfim, and the mouth of the river in 2016 and 2017 (Table 1). Sampling was always conducted after low tide began. The physicochemical parameters of the samples were measured using a Horiba U-5030 multiparameter meter.

Table 1 - Months in which water samples were taken from the Mearim Watershed

\begin{tabular}{lcc}
\hline Year & Rainy Season & Dry Season \\
\hline 2016 & January to April and June & July to September \\
2017 & April and May & November \\
\hline
\end{tabular}

\subsection{Satellite images}

Remote sensing techniques were applied to Landsat 8 satellite images obtained from the United States Geological Survey. A satellite image from the date closest to the sampling date was selected for each month of fieldwork. Images that cannot see the points were not used. 


\subsection{Development of the model}

The water quality data captured by the multiparameter meter were related to the satellite data that showed the spectral reflectance of waters in the watershed. The equations of these relationships were used to create models simulating the physicochemical properties of the entire course of the river. According to Wang and $\mathrm{Xu}$ (2008), these models have an $\mathrm{R}^{2}$ coefficient (Table 2 ) of determination used to evaluate the accuracy of the relationship in the models.

\section{RESULTS AND DISCUSSION}

\subsection{Salinity}

The water salinity levels were the highest at the mouth of the river (Figure 3) because of its proximity to the sea, where the salinity is the highest (SAMPAIO et al., 2017). At Bonfim, Porto de Santana, and Arari, the salinity of the samples from August exceeded the limit of 0.5 ppt set by Resolution $n^{\circ} 357$ of the Brazilian Environment Council. The date on which this occurred was when the tide reached its highest level (6.4 meters in São Luís) after a full moon.

Figure 4 - Salinity per period and Location

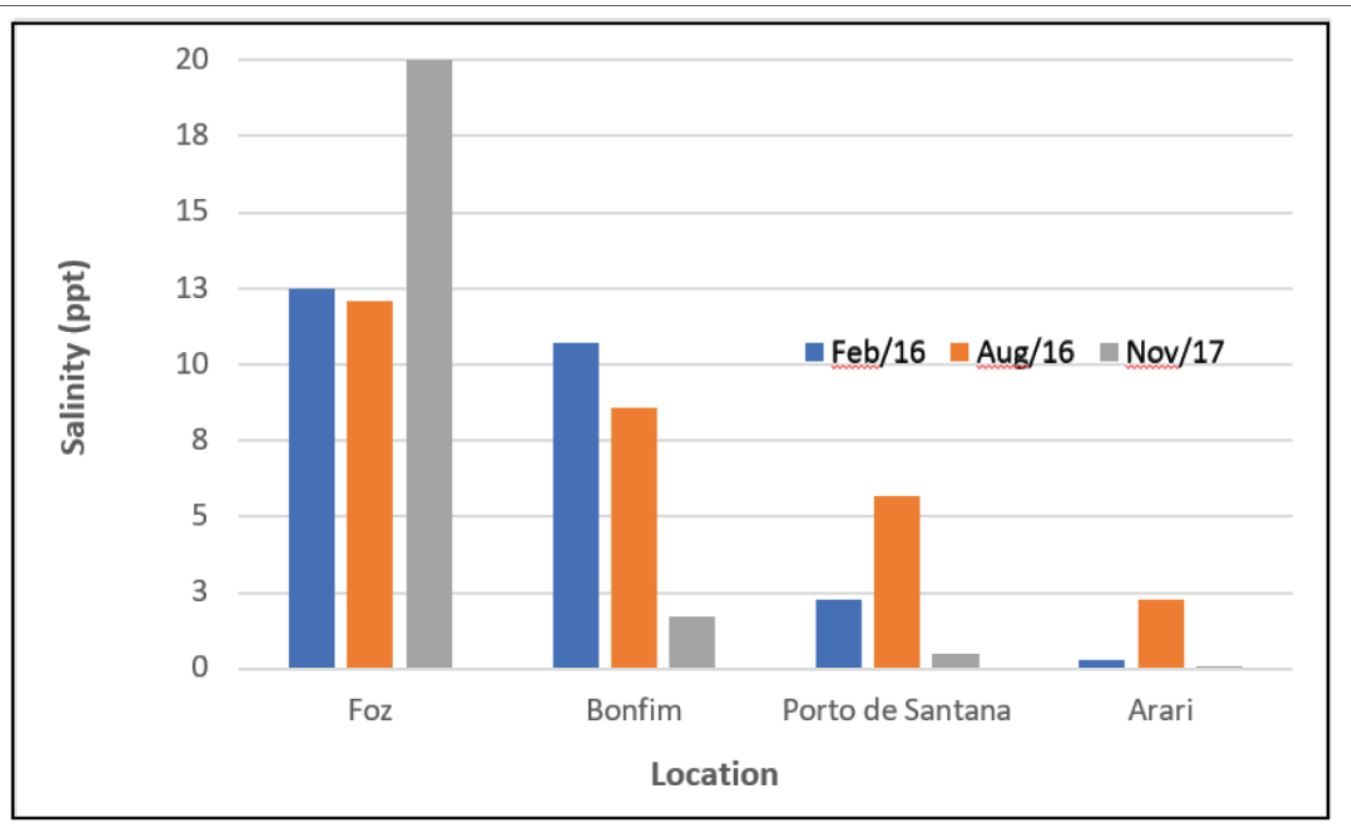




\subsubsection{Total dissolved solids}

According to CONAMA resolution $n^{\circ} 357$, the maximum limit for total dissolved solids in freshwater is $0.5 \mathrm{~g} / \mathrm{L}$. Only one sample in Arari (Figure 4) was near this level (0.44 $\mathrm{g} / \mathrm{L}$ in February); in most samples, the measured value was above this limit. Machado et al. (2007) noted that salinity is the main influence on the levels of total dissolved solids in estuarine regions. High concentrations of this class of solids (salts) limit the use of water bodies as a public water supply source (COSTA et al., 2004).

Figure 5 - Total dissolved solids (TDS) per period and location

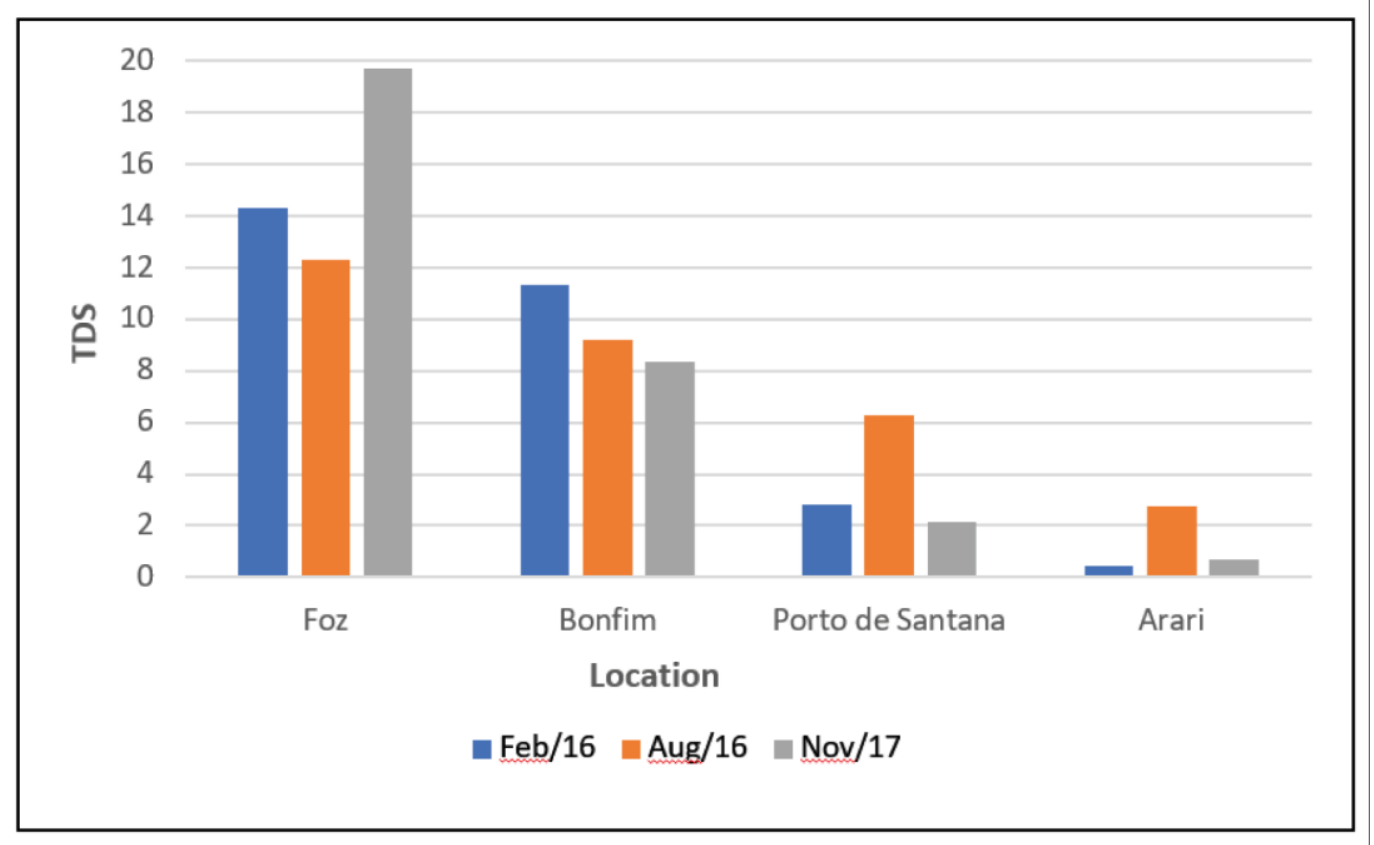

\subsubsection{Temperature}

Temperature influences several physicochemical parameters of water, such as surface tension and viscosity. Organisms that live in this habitat are very sensitive to temperatures outside their tolerance range, and the latter may have consequences for their growth and reproduction (ANA, 2017).

There was no significant difference in temperature among the sample points (Figure 5). However, in the urban area of Arari, the difference between the dry season (November) and the late rainy season (August) is approximately $3{ }^{\circ} \mathrm{C}$. The highest temperatures occurred in the dry period, for example in Foz and Porto de Santana, where the maximum temperature was $31^{\circ} \mathrm{C}$. 
Figure 6 - Temperature per period and location

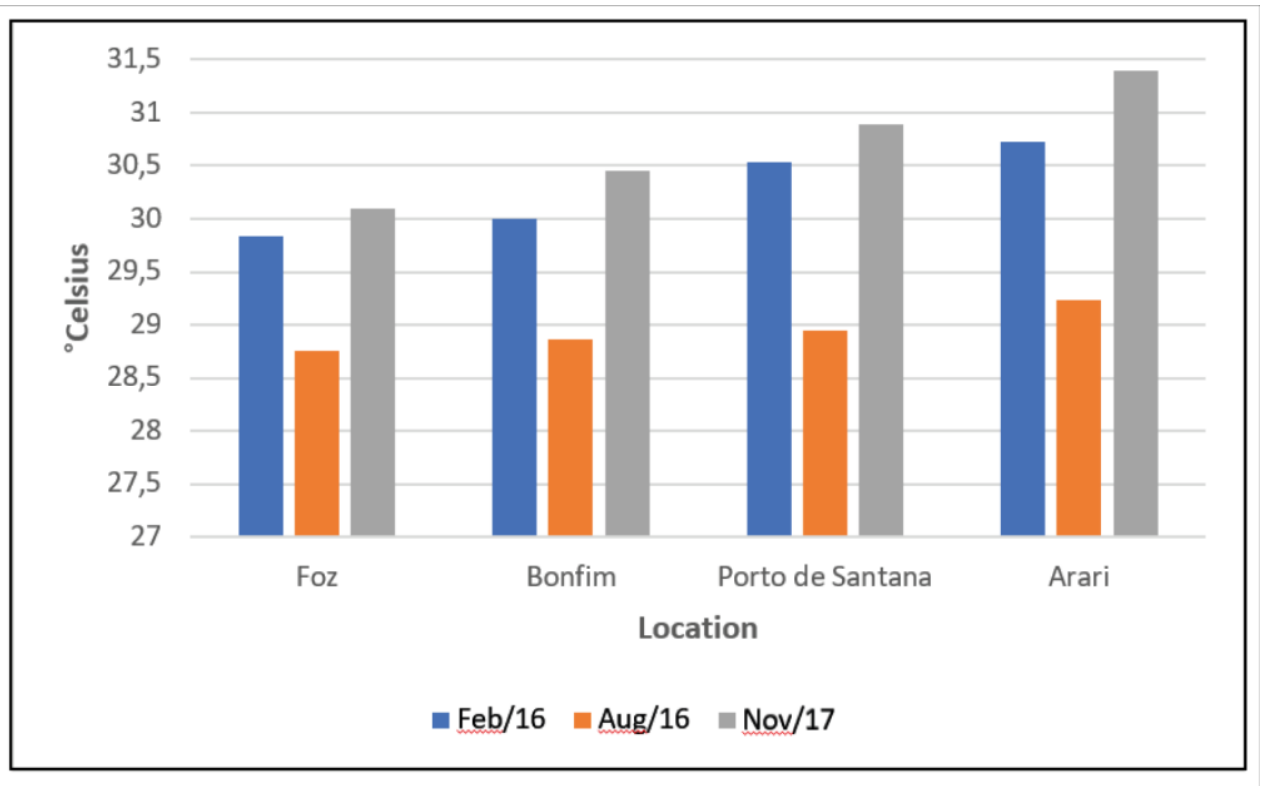

\subsubsection{Dissolved Oxygen in Water}

Considering CONAMA resolution $n^{\circ} 357$ of March 17, 2005, the limit for dissolved oxygen in brackish, i.e., class II waters (suitable for amateur fishing) is at least $4 \mathrm{mg} / \mathrm{L}$. Among the samples, the oxygen concentration was below the minimum quantity at every study site, particularly in August. From Arari to Foz, the values were 3.3, 3.28, 3.59 and 3.47 $\mathrm{mg} / \mathrm{L}$. There was also a sample below $4 \mathrm{mg} / \mathrm{L}$ in Arari $(3.85 \mathrm{mg} / \mathrm{L})$ in November.

Figure 7 - Dissolved oxygen of water per period and location

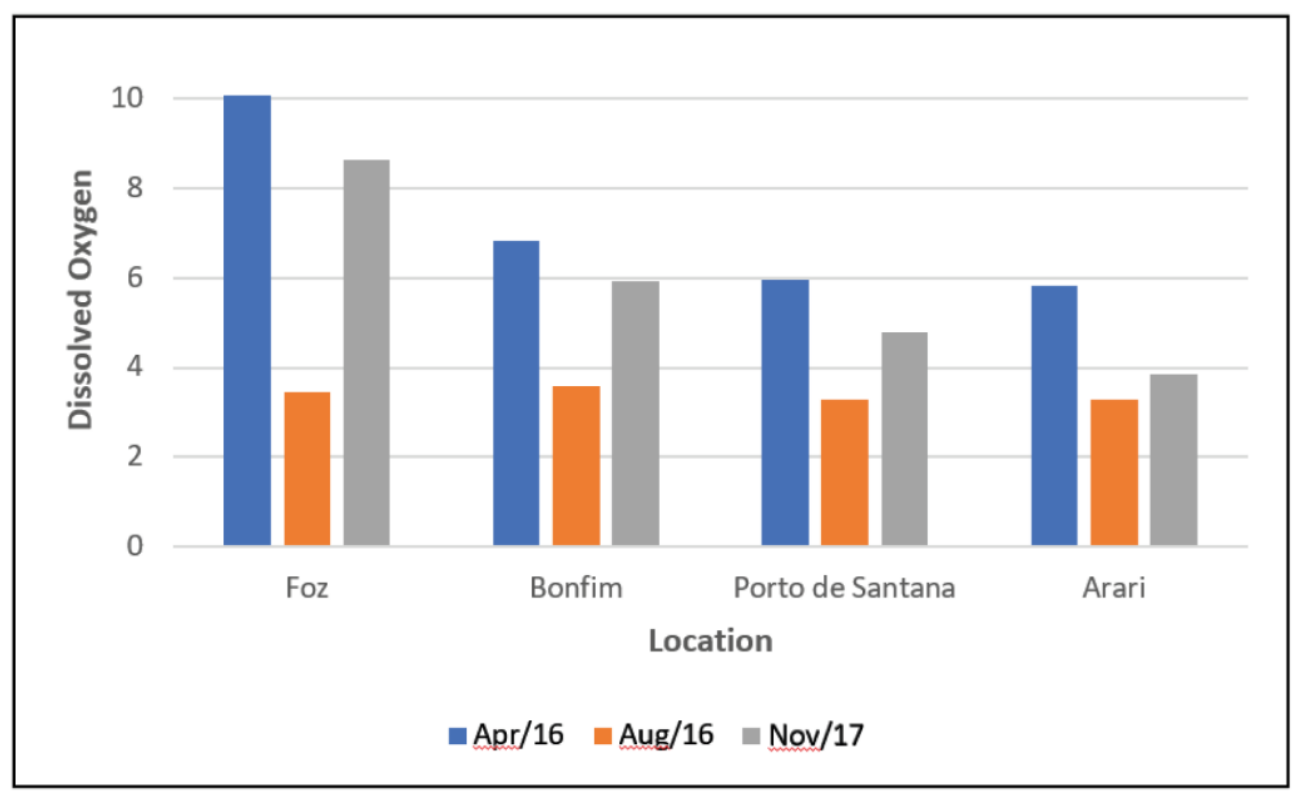


Pereira et al. (2016) found very low OD values, i.e., close to $2 \mathrm{mg} / \mathrm{L}$, during a study of the Peixe-Boi watershed in Pará. They stated that dissolved oxygen is one of the most important parameters that demonstrates the results of water pollution from organic waste.

Dissolved oxygen is necessary for marine organisms because most of them need it to breathe. Water that is polluted by sewage has a low dissolved oxygen concentration because it is used in the decomposition of organic substances. Clean water has the highest amount of dissolved oxygen, generally more than $5 \mathrm{mg} / \mathrm{L}$ (ANA, 2017).

\subsection{4 pH levels}

$\mathrm{pH}$ measurements are very important because they provide data on water quality and may indicate the presence of contaminants depending on the alkalinity or acidity of a sample (ARAÚJO, 2006).

The combination of increasing $\mathrm{pH}$ and temperature creates conditions for the formation of the $\mathrm{NH}_{3}$, which is highly toxic to fish (MIRANDA, 2017).

The $\mathrm{pH}$ limits for freshwater, according to CONAMA resolution $n^{\circ} 357$, are 6.0 to 9.0. In this regard, all samples taken were within the established limits and may not indicate pollution or any other anomaly.

Figure $8-\mathrm{pH}$ per period and location

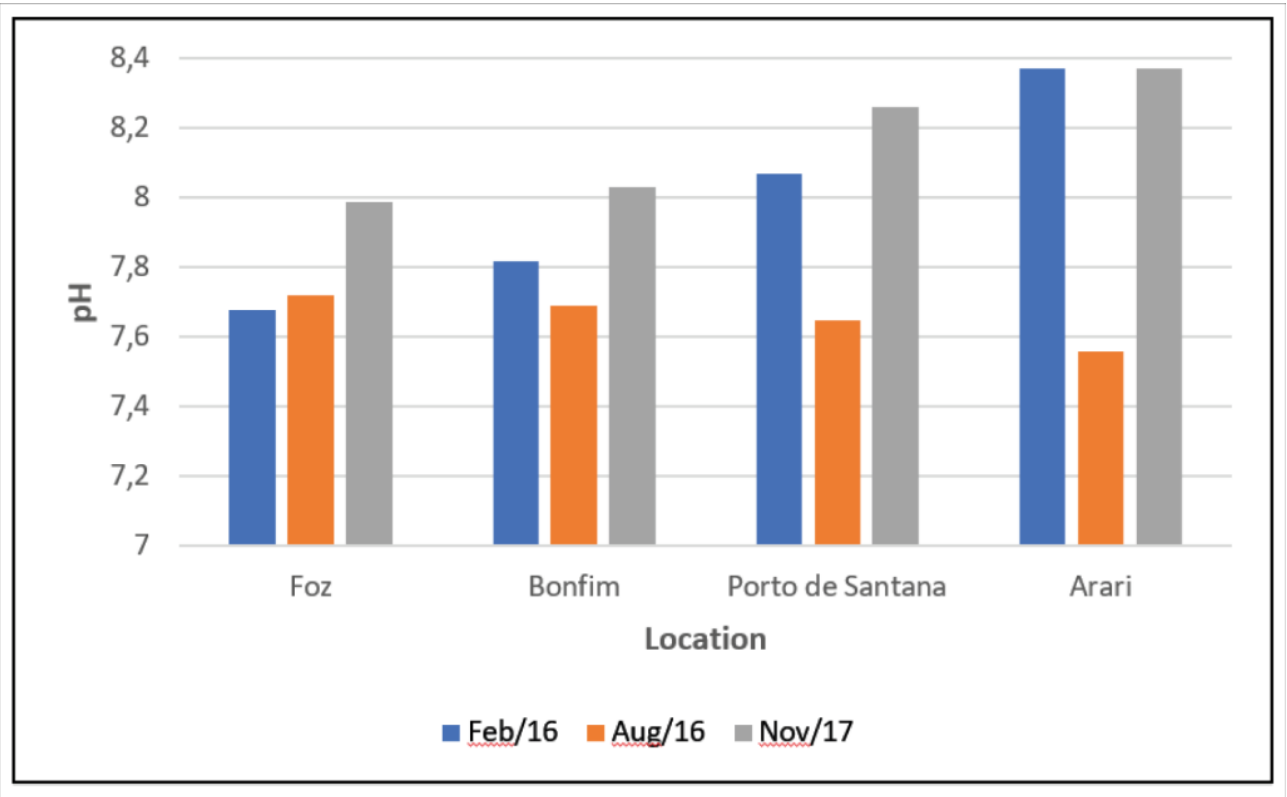




\subsection{Remote sensing the physicochemical properties of water}

The monthly equations (of june 2016, august 2016, may 2017 and november 2017) and trend lines were determined using the intersection of sampling point data and the spectral responses of the Landsat 8 images. Linear regression models and coefficients of determination $\left(\mathrm{R}^{2}\right)$ were determined from these trend lines according to Table 2. Data from the months without 10 or more qualifying points (due to clouds or cloud shadows) were not considered.

Table 2 - Linear equations and salinity determination coefficients per qualifying month

\begin{tabular}{cccc}
\hline June 2016 & August 2016 & May 2017 & November 2017 \\
\hline$y=-0.00004 x+0.0565$ & $y=-0.0062 x-3.0522$ & $y=-0.00004 x+0.1414$ & $y=-0.0074 x+16.023$ \\
$R^{2}=0.48$ & $R^{2}=0.87$ & $R^{2}=0.03$ & $R^{2}=0.23$ \\
\hline
\end{tabular}

The month with the best $R^{2}$ value $\left(R^{2}=0.87\right)$ was August 2016 .

Figures 9 and 10 were created based on the linear regression models corresponding to the physicochemical properties salinity, total dissolved solids, $\mathrm{pH}$, and temperature of the water in the region between Arari and Foz do Rio Mearim.

In terms of salinity, the highest levels were found near the mouth of the river because of its proximity to the sea. The maximum value estimated in this location was approximately $20 \mathrm{ppt}$. The level of total dissolved solids presented similar results because there were more salts present in the water near the coastal region; these levels reached up to $19.0 \mathrm{~g} / \mathrm{L}$. The opposite conditions were measured in Arari, where the total dissolved solids values were lower than $1.0 \mathrm{~g} / \mathrm{L}$.

The $\mathrm{pH}$ was alkaline, a little higher than 8.0, in the region surrounding the coastal zone. This was due to the high salt content. The $\mathrm{pH}$ value was its most acidic in Arari, at approximately 5.0. 
Detecting spatiotemporal variability ...

12

Figure 9 - Maps created using linear regression models of: A) Salinity and B) total dissolved solids

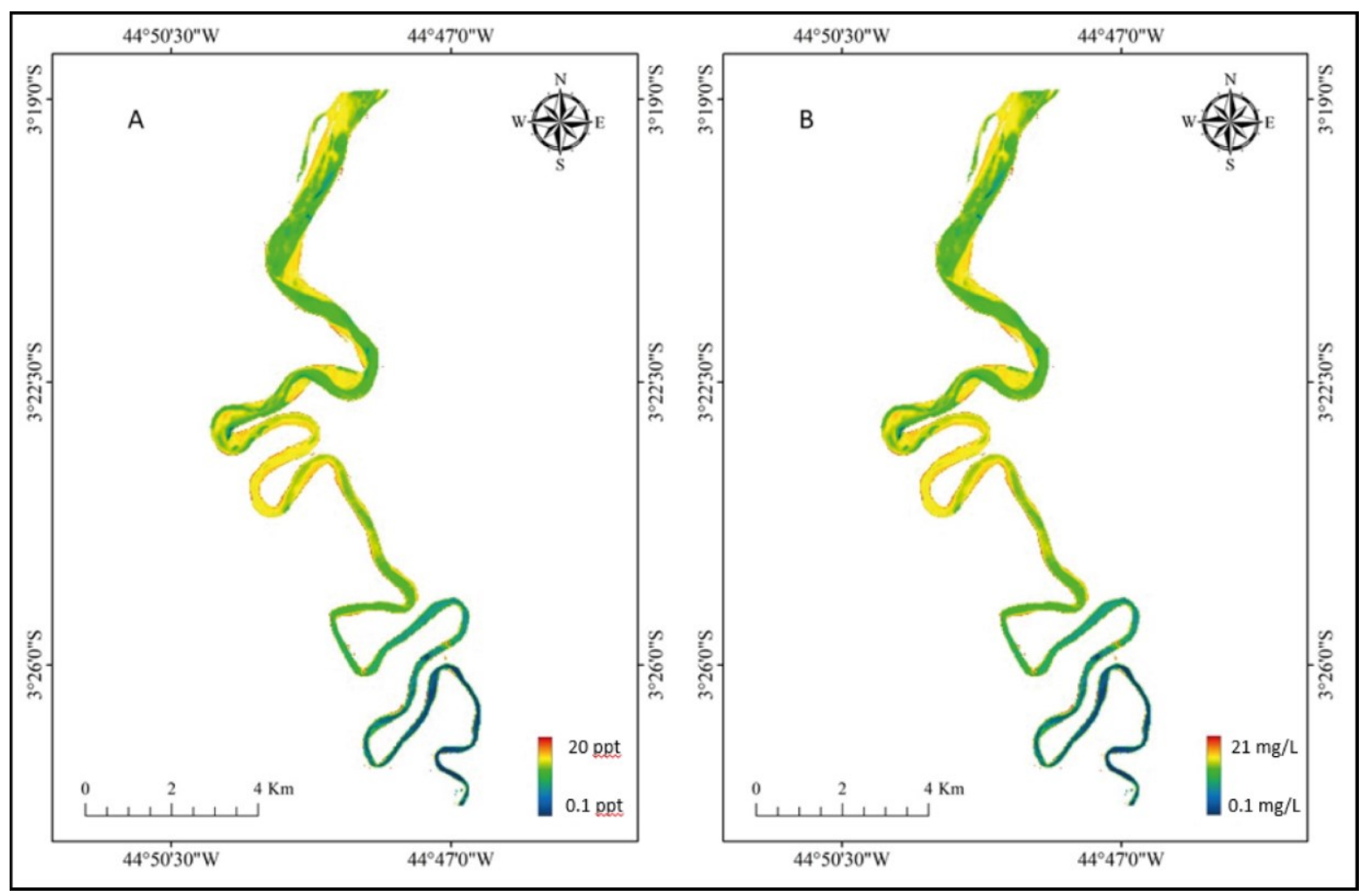

Figure 10 - Maps created using linear regression models of C) $\mathrm{pH}$ and $\mathrm{D}$ ) temperature

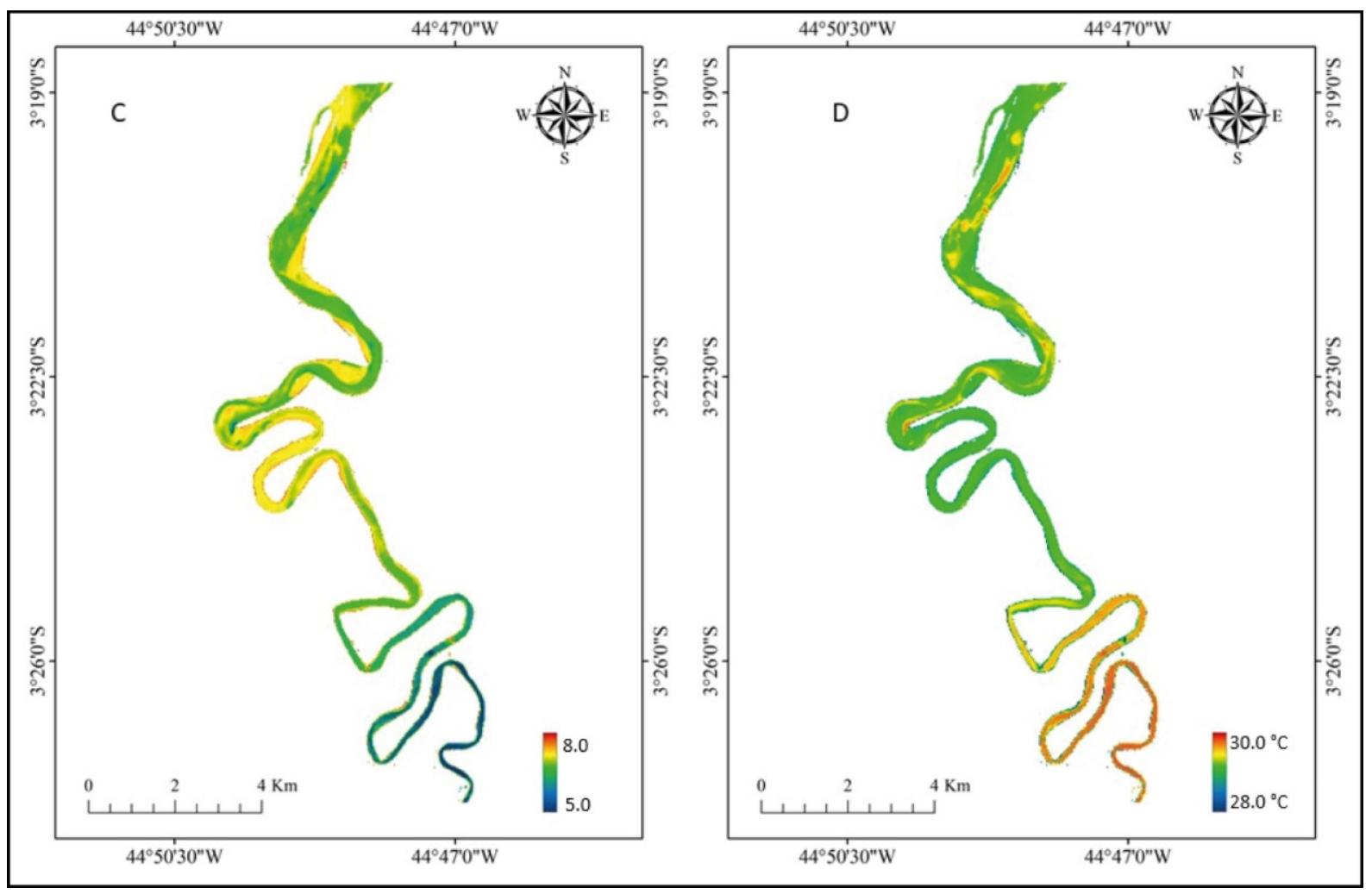

Ci. e Nat., Santa Maria, v. 42, e32, p. 1-16, 2020 
The temperature did not change much in the course of the watershed studied; it ranged between 28.0 and 31.0 degrees. The temperature was higher closer to the mouth of the river; in contrast, it was low in the samples from the city of Arari.

As the samples show existing salinity (the tidal zone of the river has practically zero salinity) and because the location is not in front of the estuarine plume (that could characterize it as coastal zone), the region studied is in the mixing zone of the estuary, as it receives water from both the watershed and the sea.

\section{CONCLUSIONS}

A survey of the physicochemical parameters of the water in lower course of the Mearim River, between its mouth and the city of Arari, was conducted in the rainy, intermediate, and dry seasons. The data, collected using a multiparameter meter, showed considerable variation. Significant salinity levels were measured at all locations; some were up to $20 \mathrm{ppt}$, which is well above the level determined by CONAMA resolution $n^{\circ}$ 357. Moreover, total dissolved solids had an approximate value of $20 \mathrm{~g} / \mathrm{L}$ and dissolved oxygen levels were insufficient; the minimum value of nearly $3 \mathrm{mg} / \mathrm{L}$ of the latter could point to a possible contamination of the estuary. Therefore, it is not advisable to use this as a resource for drinking water.

Estimating the physicochemical properties of water using remote sensing has proved to be viable, particularly in the dry season, where there is little cloud presence and thus clearer satellite images are available. Some months had sufficient numbers of qualifying points but had insufficient coefficients of determination during the creation of the regression models.

The graphs of the images of the regression models contributed to the characterization of the region as they indicated that salinity values ranged between 0.1 and 30 ppt. This, combined with the fact that the study area is not in front of the estuarine plume, confirmed the region as a mixture zone. 


\section{ACKNOWLEDGMENT}

This work was supported by the University Ceuma - UNICEUMA and FAPEMA (Brazil, MA). The authors would like to thank Dr. Fabricio Brito Silva (UNICEUMA, Brazil) for all help and friendship.

\section{REFERENCES}

AGÊNCIA NACIONAL DE ÁGUAS [Internet]. Brasília: Ministério do Desenvolvimento Regional (BR) [cited 2019 oct 31]. Indicadores de Qualidade da Água - Sistema Nacional de Informações sobre Recursos Hídrico. Available from: http://portal1.snirh.gov.br/ana/apps/webappviewer/index.html?id=b3d9cbc0b05b466 a9cb4c014eba748b3.

AGÊNCIA NACIONAL DE ÁGUAS [Internet]. Brasília: Ministério do Desenvolvimento Regional (BR) [cited 2019 oct 31]. Qualiágua. Available from: https://www.snirh.gov.br/hidroweb/publico/apresentacao.jsf.

ARAÚJO AEDM. Avaliação dos parâmetros físicos, químicos e índice de qualidade da água no rio saúde, em razão da precipitação (maio a dezembro de 2004): estudo de caso [dissertation]. Maceió/UFAL; 2006. $92 \mathrm{f}$.

BAIQIAN, S, BACH, PM, KEFENG, ZHANG, AL, COLEMAN RA, METZELING, L, MCCARTHY, DT, DELETIC, A. Understanding spatiotemporal variability of in-stream water quality in urban environments - A case study of Melbourne, Australia. Journal of Environmental Management. 2019; 246, 203-213.

BASU, S, \& ROY, A. Economic assessment of mud crab (Scylla Serrata) culture as an adaptation strategy to salinity intrusion in south-west region of Bangladesh. International Journal of Environmental Studies. 2018: 1-12.

COSTA, M, NASCIMENTO, D, OLIVEIRA, T, PEREIRA, FE. A Qualidade da Água em Pequena Comunidade: Uma Vivência de Extensão-UFBA. In: $2^{\circ}$ Congresso Brasileiro de Extensão Universitária; 2004 set 12-15; Belo Horizonte, Brasil.

DANESHVAR, N., AYAZLOO, M., KHATAEE, A. R., \& POURHASSAN, M. (2007). Biological decolorization of dye solution containing Malachite Green by microalgae Cosmarium sp. Bioresource technology, 98(6), 1176-1182.

GHOLIZADEH, MH, MELESSE, AM. Study on spatiotemporal variability of water quality parameters in Florida bay using remote sensing. Journal of Remote Sensing \& GIS. 2017; 6(3): 1- 11. 
GOVERNO DO ESTADO DO MARANHÃO. Secretaria de Estado de Planejamento, Orçamento e Gestão. Programa de planejamento e gestão territorial. São Luís (Maranhão): Governo do Estado do Maranhão; 2011.

HELLWEGER, FL, SCHLOSSER, P, LALL, U, WEISSEL, JK. Use of satellite imagery for water quality studies in New York Harbor. Estuarine, Coastal and Shelf Science. 2004; 61(3): 437-448.

HERNÁNDEZ, F, BAKKER, J, BIJLSMA L, DE BOER J, BOTERO-COYA, AM, DE BRUIND, YB. The role of analytical chemistry in exposure science: Focus on the aquatic environment. Chemosphere. 2019: 222, 564-583.

KHATTAB, M. F. O.; MERKEL, B. J. Application of Landsat 5 and Landsat 7 images data for water quality mapping in Mosul Dam Lake, Northern Iraq. Arabian Journal of Geosciences. 2014; 7(9): 3557-3573.

LI X, YUAN Y, YUAN Y, BI Z, LIU X, HUANG $Y$ et al. Effects of salinity on the denitrification efficiency and community structure of a combined partial nitritationanaerobic ammonium oxidation process. Bioresource technology. 2018; 249: 550-556.

LIU WX, LI XD, SHEN ZG, WANG DC, WAI OW, LI YS. Multivariate statistical study of heavy metal enrichment in sediments of the Pearl River Estuary. Environmental Pollution. 2003; 121(3): 377-388.

MACHADO, L P, GARÇÃO, HF, FONTANA, GH, DE OLIVEIRA, MD. Avaliação da qualidade da água da zona estuarina do rio reis magos. In: $24^{\circ}$ Congresso Brasileiro de Engenharia Sanitária e Ambiental. 2019 oct 2-7; Belo Horizonte, Brasil.

MINISTÉRIO DO MEIO AMBIENTE; Conselho Nacional de Meio Ambiente. Resolução CONAMA N 357/05. Brasília (Brasil): Ministério do Meio Ambiente; 2005. Available from: http://www.mma.gov.br.

MIRANDA EN. Qualidade das águas superficiais do rio distrito Jordão/SC: avaliada pelo IQA-índice de qualidade das águas [monography]. Palhoça: UFSC; 2017.

MIRANDA, L. CASTRO, B, KJERFVE, B. Princípios de Oceanografia: Física de Estuários. Edusp - Editora da Universidade de São Paulo. 2002: 424.

PACA, VHM, LIMA, AMM, AZAMBUJA, MAS, FORTES, JDN, SOUZA, JEF. Condições de Operação e implantação de estações da rede hidrométrica da Amazônia Oriental Estado do Pará. In: XIX Simpósio Brasileiro de Recursos Hídricos. Belém, 2011.

PEREIRA, B W DE F, MACIEL, M DE N M, OLIVEIRA, F DE A, ALVES, M A M DA S, RIBEIRO A M, FERREIRA, B M, RIBEIRO, E G P. Uso da terra e degradação na qualidade da água na bacia hidrográfica do rio Peixe-Boi, PA, Brasil. Revista Ambiente \& Água, Taubaté. 2016; 11(2): 472-485. 
PRITCHARD, DW; Advances in Geophysics. Estuarine Hydrography. Editora Elsevier. 1952: 243- 280.

REESE, A, ZIMMERMANN, T, PRÖFROCK, D, AIRRGEHER, J. Extreme spatial variation of $\mathrm{Sr}, \mathrm{Nd}$ and $\mathrm{Pb}$ isotopic signatures and 48 element mass fractions in surface sediment of the Elbe River Estuary - Suitable tracers for processes in dynamic environments? Science of The Total Environment. 2019: 668, 512-523.

RESH, VH, UNZICKER, JD. Water quality monitoring and aquatic organisms: the importance of species identification. Journal (Water Pollution Control Federation). 1975: 9-19.

SAMPAIO, CR, DE FREITAS, FR, SANTI, R, BARRELLA, W, PUSCEDDU FH, CORTEZ FS, PEREIRA CDS. Avaliação da qualidade ambiental do Rio dos Bugres, complexo estuarino de Santos e São Vicente (São Paulo, Brasil) UNISANTA. Bioscience. São Paulo. 2017 6(4): 248-257.

WANG, F, XU, YJ. Development and application of a remote sensing-based salinity prediction model for a large estuarine lake in the US Gulf of Mexico coast. Journal of Hydrology, Baton Rouge. 2008, 360: 184-194. 